\title{
Energy Efficiency Convergence across Countries in the Context of China's Belt and Road Initiative
}

\author{
Lei Han ${ }^{\mathrm{a}, \mathrm{b}^{*}}$, Botang $\mathrm{Han}^{\mathrm{a}}$, Xunpeng Shi ${ }^{\mathrm{c}, \mathrm{b}^{*}}$, Bin Su${ }^{\mathrm{b}}$, Xin $\mathrm{Lv}^{\mathrm{a}}$, Xiao Lei ${ }^{\mathrm{d}}$ \\ ${ }^{a}$ School of Management and Economics, Beijing Institute of Technology, 5 South Zhongguancun \\ Street, Haidian District, Beijing 100081, China \\ b Energy Studies Institute, National University of Singapore, 29 Heng Mui Keng Terrace, \#10-01, \\ Blk A, Singapore 119620, Singapore \\ c Australia-China Relations Institute, University of Technology Sydney, 15 Broadway, Ultimo NSW \\ 2007, Australia \\ d School of Information Management, Beijing Information Science and Technology University, \\ NO.12 Xiaoying East Road, Qinghe, Haidian District, Beijing 100192,China \\ *Corresponding authors. hanlei1990@126.com (L Han); xunpeng.shi@gmail.com (X \\ Shi).
}

\begin{abstract}
After China launched its "Belt and Road" (BR) initiative, the international community became concerned that it may worsen the environmental performance of the BR countries. Due to a lack of data for empirical testing, this paper addresses this concern through an indirect method and draws the implications of the potential impacts of China's BR initiative. This method empirically examines the effects of trade integration and regional cooperation, two major functions of the BR initiative, on energy efficiency (EE) convergence, a concept that describes the catching up process of EE across countries. A sample of 89 countries was selected to analyse the process of EE convergence from 2000 to 2014. The results indicate that although the gaps in EE among countries around the world become larger after 2010, regional cooperation may lead to a convergence process. It also finds that trade integration has a positive influence on convergence across the countries, especially among middle- and low-income countries. The results suggest that the BR initiative, through its roles in trade integration and regional cooperation, may promote EE convergence among countries. This is a desirable environmental outcome. This research also provides policy implications for both China and the other BR countries.
\end{abstract}

Key words: energy efficiency; convergence; trade integration; regional cooperation; 'Belt and Road'; China 


\section{Introduction}

Facing increasing tension between economic growth and climate change mitigation, energy efficiency (EE) is regarded as a key measure for reconciling the conflict. EE can decouple economic growth from energy demand and is considered the "most available, secure and affordable energy resource" to achieve sustainable development. It has, for some time, been a priority for energy and economic policy makers around the world [1]. For example, from 1971 to 2015, the world economy grew 22.9 times, while the total final energy consumption and total $\mathrm{CO}_{2}$ emissions in 2015 were only about 2.2 and 2.3 times their 1971 levels, respectively [2].

Apart from EE itself, against the background of equitable growth and achieving the targets of "Sustainable Energy for All (SE4ALL) 1 "by 2030, EE convergence has renewed its status as a key academic and policy topic in the EE literature and deserves continuous study. EE convergence, which means that lagging countries or regions grow faster in EE than advanced ones [3], has an additional implication for inclusive growth and narrowing the gaps in EE across countries $[4,5]$. A serious issue relating to large gaps is that the economic development and living standards of less developed countries will be affected by a lack of access to energy. More broadly, unbalanced and unequal energy use may undermine the new drivers of the world's economy in the long run and may worsen inequality around the world.

The debate over the EE convergence has a new relevant policy contribution that will help clarify the controversy surrounding the Belt and Road (BR) initiative proposed by China in 2013. The intention of the BR initiative, which comprises the Silk Road Economic Belt and the 21st Century Maritime Silk Road, is to build a trade and infrastructure network connecting Asia with Europe and Africa along the ancient Silk Road routes. Strengthening energy cooperation with countries along the BR route is a priority and significant pillar of the BR activities [6]. The BR initiative in the energy sector is not without controversy. On one hand, it is expected to have many positive impacts, such as finance, infrastructure. The BR initiative is also expected to improve

\footnotetext{
${ }^{1}$ http://www.se4all.org/about-us.
} 
energy security for China and its partners through its enhancing of EE and its production of an increased and cleaner energy supply. On the other hand, the international community is concerned that the BR initiative may precipitate a relocation of China's outdated industries to other countries, resulting in a deterioration of their environment and energy performance [7-9]. Such controversy will discourage many BR countries from participating in the initiative and prevent them from benefitting from the technology, finance and expertise that are likely to be made available through the initiative.

Examining the controversy will help both China and the BR countries understand the potential adverse impacts of the initiative, clarify whether the initiative will narrow the gaps in EE among the member economies or not, and also provide practical information for policy makers in China and the other BR countries. Despite its significance, no data are available for empirical tests because the BR initiative was only proposed recently and its implementation will take further time.

This paper tries to measure the impact of the BR initiative on EE convergence through an indirect method: a comparison of the general trend in the world and some typical regional blocks. It then draws implications about the future impact of the BR on EE convergence. The BR can affect EE convergence through its cooperation priorities in trade and regional cooperation. Achieving unimpeded trade is one of the five cooperation priorities in the BR initiative. The trade improvement could also be supported by other cooperation priorities such as facilities connectivity and financial integration [6]. Strengthening regional cooperation is another priority of the BR initiative. According to the BR Vision and Action, the policy coordination priority, one of the five priorities, aims to "promote intergovernmental cooperation..., work out plans and measures for regional cooperation, negotiate to solve cooperation-related issues...”[6].

Applying various convergence assessment techniques with consideration given to spatial effects, this research projects how the BR initiative may affect cross-country EE convergence by examining the impact of trade and regional cooperation on EE convergence. Past studies find that trade is important in explaining the process of EE 
convergence [10, 11]. In Europe, for example, trade —especially the knowledge spillover that it facilitates — advances the EE convergence among European Union (EU) countries [12]. To emphasise the interdependence among countries, trade could also be described as trade integration [13-17]. Regional cooperation could also promote EE convergence across countries. Regional cooperation mechanisms (RCMs), such as the Asia-Pacific Economic Cooperation (APEC), the Association of Southeast Asian Nations (ASEAN), the Organization for Economic Co-operation and Development (OECD) and the EU, affect EE convergence across countries through non-trade measures, such as investment, information sharing, international technology and expertise transfer [18-20].

The contributions of this paper are: (a) it assesses a major international policy concern that the BR may cause deterioration of the environment in other countries. The results provide opportunistic justification that may facilitate its development and inform policy makers in China and other countries in terms of policy development; (b) it demonstrates that the BR initiative can impact the environment through two channels: trade integration and regional cooperation. This framework will be useful in assessing the impact of the BR initiative in the future; and (c) it proposes a specific definition and measurement of trade integration emphasizing the relationship with China.

The structure of the paper is as follows. Section 2 summarises the relevant literature, section 3 presents the methodology and data, section 4 reports and interprets the empirical analytical results of the spatial convergence models, section 5 discusses the implications of this study concerning the BR initiative, and the conclusion is presented in Section 6.

\section{Literature review}

In the research on EE convergence, the terms $\sigma$-convergence and $\beta$-convergence are often employed to describe the process. $\sigma$-convergence means a decrease in the cross-country differences typically measured by the standard deviation [3]. $\beta$ convergence refers to the rate of growth being high in the initial stage but falling as EE increases, approaching the steady state [3]. 
International trade has been explored as an influential factor in the EE convergence. New technology embodied in capital equipment can spill over to other countries through foreign direct investment and international trade [21] and, thus, lead to convergence of energy productivity. In addition, sector specialisation resulting from international trade may lead to the adjustment of the industrial structure. The proportion of energy-intensive industry in an economy can affect the performance of EE directly and may make a difference in EE convergence across countries [11, 22-24]. Moreover, international trade has been explored as an influential factor leading to changes in the industrial structure through the change of production patterns [11, 12, 25]. At the same time, in the view of trade and measuring the interdependence among specific countries in the literature, trade integration is a positive driver of EE convergence [11].

In addition to international trade, various channels of regional cooperation mechanisms, such as energy integration, can promote more equitable energy access. It may also help low efficiency countries catch up with high efficiency countries [4]. Since different regional cooperation groups have their own characteristics in their use of energy, they usually perform differently in EE convergence. The existing literature finds that regional groups have specific focuses in terms of EE convergence. For the OECD countries, the trend in $\mathrm{EE}$ predominantly has an impact on the pattern of the convergence, while structural effects may undermine this process $[11,23]$. The reduction in gaps in EE comes mainly from consumption efficiency convergence at the sector level [26]. In the scope of the EU, trade intensity is a significant influential factor, while the effect from sector specialisation is not clear [12]. To catch up with the level of the EU average, reforms in governance and in the market have been recommended for the transition countries of Eastern Europe [27]. In the ASEAN, energy integration is considered an important driver of EE convergence [4].

Considering the methods used in the previous studies to explore the process of convergence, a standard $\beta$-convergence model, based on the neoclassical growth model is often used [3, 28]. With this method, the evolution and influential factors of convergence have been revealed $[3,10,12,17,21,27-36]$. Due to some misspecification from unaccounted-for spatial effects [37, 38], the basic model has also 
been improved with the spatial econometric method to deal with the spatial externalities of geographical distance, contiguity and economical distance, such as bilateral trade $[12,29,30,36]$. The weight matrixes in spatial econometric models are further constructed in various forms [12, 29, 30, 36]. Decomposition analysis is another main method used in research on EE convergence. Index decomposition analysis (IDA) and its improved models are used frequently in existing research [11, 23, 24, 26]. Compared with an econometric model, IDA can explore the mechanism of changes in the use of energy from the view of system engineering [39, 40]. In addition, some statistical descriptions have been employed to measure the differences among countries. For example, the standard deviation is usually used to describe $\sigma$-convergence, mentioned above [5, 10-12, 17, 21, 23, 29, 41].

The research on the BR initiative in the literature includes mainly two aspects. One group of research reviews motivation, framework, assessment and issues on the BR initiative [7-9, 42-46]. A large proportion of papers hold positive opinions, while others raise concerns about the environmental effects and energy consumption and availability [7-9]. The other group of studies are quantitative analyses in the area of the BR. At present, this kind of research is limited, and has some problems [47, 48]. For example, Du and Zhang employed a Difference-in-Difference model to estimate the effects of the BR initiative on Chinese overseas direct investment. However, this research set 2014 to 2015 as the post-strategy period directly without considering the lagging effects of policy [48]. In the studies focusing on the field of energy and the BR initiative, the topics relate to energy investment [47], energy security [45], clean energy [46], energy cooperation [44], etc.

Above all, some of the shortcomings of the previous studies are addressed in this paper. First, although there are various studies among regional cooperation mechanisms on EE convergence, none address the issues about the BR initiative. Furthermore, there are no quantitative analyses on the effects of trade integration and other kinds of regional cooperation in the literature studying convergence. Second, in the studies on the BR initiative, empirical research is quite rare, and the influence of specific determinants cannot be implied effectively. Studies within the scope of EE and its 
convergence are even scarcer. Third, in the previous research, the definition of trade integration is quite simplistic and cannot measure the elasticity of its effects precisely [13-15]. In addition, the special status of founding countries in the regional cooperation is ignored generally in its definition $[16,17]$.

To solve these problems, following the method of Mulder and Wan [11, 12], this study estimates the impact of trade integration and regional cooperation on EE convergence. It considers spatial effects and discusses the implications for scenarios of countries under China’s BR initiative (called BR countries in this study).

\section{Methodology and data}

\subsection{Methodology}

This study first estimates the general trends around the world and then focuses on four typical regional cooperation mechanisms that are comparable to the BR initiative. Finally, the implications are discussed according to the comparisons.

Here, $\sigma$-convergence and $\beta$-convergence are selected to describe the process. This study first observes the phenomenon of $\sigma$-convergence in the world's $\mathrm{EE}$ and then in selected country groups. Equation (1) provides the formula:

$\sigma_{t}=\sqrt{\frac{1}{n} \sum_{i=1}^{n}\left(\ln E E_{i t}-\overline{\ln E E_{i t}}\right)^{2}}$

where $\sigma_{t}$ is the standard deviation across countries in year t, $E E_{i t}$ is the energy efficiency of country $\mathrm{i}$ in year $\mathrm{t}$, and $\mathrm{n}$ is the number of countries.

Then, a regression model is built to explore the $\beta$-convergence process. The standard $\beta$-convergence specification is as follows:

$\ln \left(\frac{E E_{i t}}{E E_{i, t-1}}\right)=C+\beta \ln \left(E E_{i, t-1}\right)+\delta X_{i t}+\varepsilon_{i t}$

where $E E_{i t}$ is the energy efficiency of country $\mathrm{i}$ in year t, C is a constant, $X_{i t}$ represents the conditional variables and $\varepsilon_{i t}$ is an error term. $\beta$, which is the key coefficient in this model, measures the speed of convergence. If $\beta$ is negative and significantly different from zero, $\beta$-convergence is demonstrated. Furthermore, it is called absolute $\beta$ convergence if $\delta$ is insignificant and conditional $\beta$-convergence otherwise.

Following Wan [12], spatial effects are considered in this research to control for 
factors that may explain the change in EE across different countries. Equation (2) is estimated with a spatial panel data model, which may extract unobserved factors derived from spatial effects in the error term of the original model. The entity fixedeffects model is applied to control for the constant difference between different observations. In this structure, the standard $\beta$-convergence specification can be transformed into either the form of a spatial lag model (SAR) or a spatial error model (SEM), shown as Equations (3) and (4) [12]:

SAR: $\ln \left(\frac{E E_{i t}}{E E_{i, t-1}}\right)=C+\beta \ln \left(E E_{i, t-1}\right)+\delta X_{i t}+\rho W \ln \left(\frac{E E_{i t}}{E E_{i, t-1}}\right)+\varepsilon_{i t}$

$\mathrm{SEM}: \ln \left(\frac{E E_{i t}}{E E_{i, t-1}}\right)=C+\beta \ln \left(E E_{i, t-1}\right)+\delta X_{i t}+\varepsilon_{i t}, \varepsilon_{i t}=\rho W \varepsilon_{i t}+\tau_{i t}$

where $W$ denotes a spatial weight matrix.

Given the finding in previous studies that industries or firms can raise their productivity through international trade with technologically advanced partners [49], following Wan [12], this research constructs a trade-based spatial weight matrix with an assumption about how regional externalities occur [50]. The trade flow-based spatial weight matrix is defined as follows:

$\mathrm{W}=\left[\begin{array}{ccc}0 & \cdots & T F_{1 n} \\ \vdots & \ddots & \vdots \\ T F_{n 1} & \cdots & 0\end{array}\right]$

where $\mathrm{TF}$ denotes the bilateral trade flow, defined as the sum of imports and exports between two countries, and $\mathrm{n}$ is the number of countries in the study. The diagonal value in the matrix is set to zero, indicating that domestic trade is not considered.

For the empirical estimation, three steps are followed. First, a simple unconditional EE convergence equation is estimated, controlling only for the energy efficiency levels in the last period and the spatial effects from trade partners. Next, the research estimates a conditional convergence equation, controlling for various characteristics of a country. Lastly, the way in which factors such as trade integration and other regional cooperation affect EE convergence is explored.

\subsection{Data and variables}

This analysis is based mainly on eight data sources. Data on countries' economy 
and energy are taken from the World Development Indicators, the CEIC database, the IEA World Energy Balance, the WIPO statistics database, the BP Statistical Review of World Energy and the database published by the National Bureau of Statistics of China. The bilateral trade flow is retrieved from the UN Comtrade database. The geographical distance between countries is collected from the GeoDist database developed by the CEPII.

Due to data availability, to make the sample set as large as possible, the designated time period was 2000 to 2014 and it included 89 countries. Since these 89 countries contribute to nearly $80 \%$ of GDP and $70 \%$ of the TFC around the world, the performance of these countries can represent the general status of the world economy and energy usage and efficiency, to some extent. In the sample, there are 37 countries belonging to the BR initiative. The details are presented in Table 1 . The summary statistics shown there are for 18 European countries, 18 Asian countries, and one African country. By contrast, the composition of the 65 BR economies (excluding China) is 22 European countries, 42 Asian countries and 1 African country. Although 24 Asian countries in the BR scope are not included in the sample, some influential economies, like the the Russian Federation, India, Singapore and some energy-rich lands, such as the United Arab Emirates, Saudi Arabia and Qatar are all considered in this research. In addition, this sample covers nearly all developed countries among the BR countries, except Israel. Therefore, the 37 countries are effective representatives for the BR initiative in terms of both economy and energy. The distribution of continents is collected from the GeoDist database, and the development level is based on the classification of the International Monetary Fund (IMF).

\section{Table 1}

Summary statistics of the BR countries in data set

\begin{tabular}{|c|c|c|c|c|c|}
\hline Countries & $\begin{array}{l}\text { Development } \\
\text { level }\end{array}$ & Continent & Countries & $\begin{array}{l}\text { Development } \\
\text { level }\end{array}$ & Continent \\
\hline Albania & & Europe & Bahrain & & Asia \\
\hline Bulgaria & & Europe & Bangladesh & & Asia \\
\hline Belarus & & Europe & Cambodia & & Asia \\
\hline Croatia & & Europe & Sri Lanka & & Asia \\
\hline Cyprus & Developed & Europe & Indonesia & & Asia \\
\hline
\end{tabular}




\begin{tabular}{lllll}
\hline Czech Republic & Developed & Europe & Kazakhstan & Asia \\
Estonia & Developed & Europe & Jordan & Asia \\
Greece & Developed & Europe & Lebanon & Asia \\
Hungary & & Europe & Malaysia & Asia \\
Latvia & Developed & Europe & Philippines & Asia \\
Lithuania & Developed & Europe & Qatar & Asia \\
Moldova & & Europe & Russian Federation & Asia \\
Poland & & Europe & Saudi Arabia & Asia \\
Romania & & Europe & India & Asia \\
Slovak Republic & Developed & Europe & Singapore & Asia \\
Slovenia & Developed & Europe & Viet Nam & Asia \\
Turkey & & Europe & Thailand & Asia \\
Ukraine & & Europe & United Arab & Asia \\
& & & Emirates & \\
& & & Egypt & Africa \\
\hline
\end{tabular}

In this paper, energy efficiency is measured as the ratio of the gross domestic product (GDP) (in constant 2000 dollars) to the total final consumption (TFC). The data on the TFC were collected from the IEA World Energy Balance.

The analysis adopts a new approach for defining trade integration, which is a key variable in this study. The definitions of trade integration in the literature are presented in Table 2. Most of the existing studies use a dummy variable (Form 3) to measure the effects of trade integration, but this method cannot measure the degree of integration in a specific group and thus cannot capture dynamics. The two remaining forms (Form 1 and Form 2) seem to be similar. However, Form 1 relates mainly to the energy market, and Form 2 does not consider the effects from a geographical distance.

\section{Table 2}

Forms of trade integration in existing studies

\begin{tabular}{|c|c|c|}
\hline No. & Formula & Source \\
\hline 1 & $\frac{1}{n T F C_{i t}} \sum_{j=1}^{n} \frac{\text { imports }_{i j t}+\text { exports }_{i j t}}{\text { distance }_{i j}}$ & Sheng and Shi [17] \\
\hline 2 & The ratio of imports plus exports to GDP & Vithessonthi and Kumarasinghe [16] \\
\hline 3 & $\begin{array}{l}\text { A dummy variable testing whether two } \\
\text { countries are members of the same regional } \\
\text { integration agreement }\end{array}$ & $\begin{array}{l}\text { Bahmani-Oskooee et al. [15] } \\
\text { Geldi [14] } \\
\text { Sheng et al. [13] }\end{array}$ \\
\hline
\end{tabular}

In this paper, to solve these two problems, Forms 1 and 2 are combined with 
geographical effects. ${ }^{2}$ The trade integration variable is calculated as the weighted average of imports and exports between sample countries and China to emphasise the international concerns about trade with China in the BR initiative. Since China is used as the reference group in the definition, it is not explicitly included in the sample analysis.

The weight is determined by the geographical distance between the capitals of the countries. To consider the size heterogeneity of the economy of the different countries, the study divides the weighted average by the GDP across countries. Following this definition, trade integration provides information about the effects of trade on the boosting of the dependence on bilateral trade with China. The definition is shown as Equation (6):

$T I_{i t}=\frac{\text { imports }_{i t}+\text { exports }_{i t}}{G D P_{i t} \times \text { distance }_{i}}$

where $T I_{i t}$ stands for the trade integration of country $\mathrm{i}$ in year $\mathrm{t}$, imports it $_{i t}$ and exports $_{i t}$ are country i's imports and exports with China in year $\mathrm{t}$, distance $_{i}$ represents the geographical distance between the capital of country $i$ and Beijing, the capital of China and $G D P_{i t}$ is the GDP of country $\mathrm{i}$ in year $\mathrm{t}$.

The energy mix is also highly related to energy efficiency performance and thus is included in the model. Coal and oil are less efficient than other types of energy [12, 5153]. To control for the effects of the proportion of relative less efficient energy in production, energy mix is included in the model, which is measured explicitly as shown in Equation (7).

$E M_{i t}=\frac{T F C_{-}{ }_{c o a l} l_{i t}+T F C_{-} o i l_{i t}}{T F C_{i t}} \times 100 \%$

where $E M_{i t}$ represents country i's energy mix in year t, $T F C_{-}$coal $_{i t}$ is country i's total final consumption of coal and coal products, $T F C_{-} o i l_{i t}$ is country i’s total final consumption of oil products and $T F C_{i t}$ represents country i's total final consumption in year $\mathrm{t}$.

As energy efficiency in this study focuses mainly on the national level, the

\footnotetext{
${ }^{2}$ Given that the definition in the research is not similar to the traditional formula of the gravity model as Form 1, this paper conducts the Pearson Correlation Test between Form 1 (changing TFC to GDP) and Equation 6. The coefficient is 0.303 , significant at a $1 \%$ level, meaning that the regression results will not be affected.
} 
industrial structure is also a key factor. Greater dependence of an economy on energyintensive sectors, like the manufacturing industry, may lead to lower energy efficiency [54]. In addition, carbon leakage, which results from enterprises avoiding stringent climate policies, will result in changes in the industrial structure. The industrial structure is defined as the ratio of the industrial value added to the GDP as shown in Equation (8):

$I S_{i t}=\frac{I V A_{i t}}{G D P_{i t}} \times 100 \%$

where $I S_{i t}$ represents the industrial structure of country i in year $\mathrm{t}, I V A_{i t}$ stands for country i's industrial value added in year $t$ and $G D P_{i t}$ is the GDP of country $\mathrm{i}$ in year $t$.

\subsection{Model tests}

Before the estimation, a stationarity test on the variables was conducted. The ADFFisher, PP-Fisher [55] and LLC [56] methods were used to check the stationarity properties of the data using Eviews 9. The results in Table 3 indicate that, except for the growth rates of $\mathrm{EE}$ and the energy mix which are stationary at level, the other variables are all stationary at the first difference.

Table 3 Stationarity test results

\begin{tabular}{|c|c|c|c|c|c|c|}
\hline \multirow[b]{2}{*}{$\begin{array}{l}\text { Statistics } \\
\text { (p-value) }\end{array}$} & & \multirow{2}{*}{$\begin{array}{l}\text { ADF } \\
\text { ADF- } \\
\text { Fisher chi- } \\
\text { square }\end{array}$} & \multirow[b]{2}{*}{$\begin{array}{l}\text { ADF-Choi } \\
\text { Z-stat }\end{array}$} & \multirow{2}{*}{$\begin{array}{l}\text { LLC } \\
\text { Levin, Lin } \\
\text { and Chu t* }\end{array}$} & \multicolumn{2}{|l|}{$\mathrm{PP}$} \\
\hline & & & & & $\begin{array}{l}\text { PP-Fisher } \\
\text { chi-square }\end{array}$ & $\begin{array}{l}\text { PP-Choi Z- } \\
\text { stat. }\end{array}$ \\
\hline \multirow{3}{*}{ g } & Level & $\begin{array}{l}440.062^{* * *} \\
(0.000)\end{array}$ & $\begin{array}{l}-11.811^{* * *} \\
(0.000)\end{array}$ & $\begin{array}{l}-10.608^{* * *} \\
(0.000)\end{array}$ & $\begin{array}{l}929.145^{* * * *} \\
(0.000)\end{array}$ & $\begin{array}{l}-22.574 * * * \\
(0.000)\end{array}$ \\
\hline & $\begin{array}{l}\text { First } \\
\text { difference }\end{array}$ & $\begin{array}{l}838.856 * * \\
* \\
(0.000)\end{array}$ & $\begin{array}{l}-21.449 * * * \\
(0.000)\end{array}$ & $\begin{array}{l}-19.981^{* * *} \\
(0.000)\end{array}$ & $\begin{array}{l}1861.620 * * \\
* \\
(0.000)\end{array}$ & $\begin{array}{l}-37.399 * * * \\
(0.000)\end{array}$ \\
\hline & $\begin{array}{l}\text { Second } \\
\text { difference }\end{array}$ & $\begin{array}{l}1074.420 * * \\
* \\
(0.000)\end{array}$ & $\begin{array}{l}-25.811^{* * *} \\
(0.000)\end{array}$ & $\begin{array}{l}-27.572^{* * *} \\
(0.000)\end{array}$ & $\begin{array}{l}1881.960 * * \\
* \\
(0.000)\end{array}$ & $\begin{array}{l}-38.017 * * * \\
(0.000)\end{array}$ \\
\hline \multirow{3}{*}{$\operatorname{Ln}(\mathrm{EE})$} & Level & $\begin{array}{l}118.057 \\
(1.000)\end{array}$ & $\begin{array}{l}6.810 \\
(0.000)\end{array}$ & $\begin{array}{l}-0.885 \\
(0.188)\end{array}$ & $\begin{array}{l}211.438 * * \\
(0.044)\end{array}$ & $\begin{array}{l}6.074 \\
(1.000)\end{array}$ \\
\hline & $\begin{array}{l}\text { First } \\
\text { difference }\end{array}$ & $\begin{array}{l}416.596 * * \\
* \\
(0.000)\end{array}$ & $\begin{array}{l}-10.966^{* * *} \\
(0.000)\end{array}$ & $\begin{array}{l}-11.353^{* * *} \\
(0.000)\end{array}$ & $\begin{array}{l}867.668 * * * \\
(0.000)\end{array}$ & $\begin{array}{l}-21.266^{* * * *} \\
(0.000)\end{array}$ \\
\hline & $\begin{array}{l}\text { Second } \\
\text { difference }\end{array}$ & $\begin{array}{l}797.900 * * * \\
(0.000)\end{array}$ & $\begin{array}{l}-20.460 * * * \\
(0.000)\end{array}$ & $\begin{array}{l}-21.887^{* * * *} \\
(0.000)\end{array}$ & $\begin{array}{l}1743.750 * * \\
* \\
(0.000)\end{array}$ & $\begin{array}{l}-35.788 * * * \\
(0.000)\end{array}$ \\
\hline \multirow[t]{2}{*}{ TI } & Level & $\begin{array}{l}80.444 \\
(1.000)\end{array}$ & $\begin{array}{c}7.746 \\
(1.000)\end{array}$ & $\begin{array}{c}-0.963 \\
(0.168)\end{array}$ & $\begin{array}{l}78.189 \\
(1.000)\end{array}$ & $\begin{array}{l}10.463 \\
(1.000)\end{array}$ \\
\hline & First & $503.830 * *$ & $-12.741 * * *$ & $-14.804 * * *$ & $837.003 * * *$ & $-19.894 * * *$ \\
\hline
\end{tabular}




\begin{tabular}{|c|c|c|c|c|c|c|}
\hline & difference & $\begin{array}{l}* \\
(0.000)\end{array}$ & $(0.000)$ & $(0.000)$ & $(0.000)$ & $(0.000)$ \\
\hline & $\begin{array}{l}\text { Second } \\
\text { difference }\end{array}$ & $\begin{array}{l}868.200^{* *} \\
* \\
(0.000)\end{array}$ & $\begin{array}{l}-22.023^{* * *} \\
(0.000)\end{array}$ & $\begin{array}{l}-29.982^{* * *} \\
(0.000)\end{array}$ & $\begin{array}{l}1681.350 * * \\
* \\
(0.000)\end{array}$ & $\begin{array}{l}-34.826^{* * *} \\
(0.000)\end{array}$ \\
\hline \multirow{3}{*}{ EM } & Level & $\begin{array}{l}153.759 \\
(0.905)\end{array}$ & $\begin{array}{l}1.872 \\
(0.969)\end{array}$ & $\begin{array}{l}-2.607 * * * \\
(0.005)\end{array}$ & $\begin{array}{l}187.019 \\
(0.307)\end{array}$ & $\begin{array}{c}0.969 \\
(0.834)\end{array}$ \\
\hline & $\begin{array}{l}\text { First } \\
\text { difference }\end{array}$ & $\begin{array}{l}436.057^{* * *} \\
(0.000)\end{array}$ & $\begin{array}{l}-11.114^{* * *} \\
(0.000)\end{array}$ & $\begin{array}{l}-9.643^{* * *} \\
(0.000)\end{array}$ & $\begin{array}{l}901.430 * * * \\
(0.000)\end{array}$ & $\begin{array}{l}-21.581^{* * *} \\
(0.000)\end{array}$ \\
\hline & $\begin{array}{l}\text { Second } \\
\text { difference }\end{array}$ & $\begin{array}{l}731.685^{* *} \\
* \\
(0.000)\end{array}$ & $\begin{array}{l}-19.163^{* * *} \\
(0.000)\end{array}$ & $\begin{array}{l}-19.391^{* * *} \\
(0.000)\end{array}$ & $\begin{array}{l}1700.380 * * \\
* \\
(0.000)\end{array}$ & $\begin{array}{l}-35.196^{* * *} \\
(0.000)\end{array}$ \\
\hline \multirow{3}{*}{ IS } & Level & $\begin{array}{l}163.714 \\
(0.771)\end{array}$ & $\begin{array}{l}0.354 \\
(0.638)\end{array}$ & $\begin{array}{l}-4.462 * * * \\
(0.000)\end{array}$ & $\begin{array}{l}204.297 * \\
(0.086)\end{array}$ & $\begin{array}{l}-0.244 \\
(0.404)\end{array}$ \\
\hline & $\begin{array}{l}\text { First } \\
\text { difference }\end{array}$ & $\begin{array}{l}440.646^{* * *} \\
(0.000)\end{array}$ & $\begin{array}{l}-11.707^{* * *} \\
(0.000)\end{array}$ & $\begin{array}{l}-13.986^{* * *} \\
(0.000)\end{array}$ & $\begin{array}{l}821.671 \text { *** } \\
(0.000)\end{array}$ & $\begin{array}{l}-20.478^{* * *} \\
(0.000)\end{array}$ \\
\hline & $\begin{array}{l}\text { Second } \\
\text { difference }\end{array}$ & $\begin{array}{l}718.665^{* * *} \\
(0.000)\end{array}$ & $\begin{array}{l}-19.183^{* * *} \\
(0.000)\end{array}$ & $\begin{array}{l}-23.253^{* * *} \\
(0.000)\end{array}$ & $\begin{array}{l}1764.540 * * \\
* \\
(0.000)\end{array}$ & $\begin{array}{l}-36.060^{* * *} \\
(0.000)\end{array}$ \\
\hline
\end{tabular}

${ }^{*}, * *$ and ${ }^{* * *}$ represent significance at the $10 \%, 5 \%$ and $1 \%$ level, respectively. The $\mathrm{p}$-value is shown in parentheses.

Beside the stationarity tests, this paper examines the co-integration relationship in this model using the Pedroni and KAO tests $[57,58]$. The results of the co-integration test shown in Table 4 indicate that most of the statistics reject the null hypothesis that a co-integration relationship does not exist.

Table 4 Co-integration test results

\begin{tabular}{llllll}
\hline & & Statistic & Prob. & $\begin{array}{l}\text { Weighted } \\
\text { statistic }\end{array}$ & Prob. \\
\hline Pedroni & $\begin{array}{l}\text { Panel v-statistic } \\
\text { Panel rho- } \\
\text { statistic }\end{array}$ & $1.803^{* *}$ & 0.036 & 0.725 & 0.234 \\
& $\begin{array}{l}\text { Panel PP- } \\
\text { statistic }\end{array}$ & -15.083 & 0.999 & 4.147 & 1.000 \\
& $\begin{array}{l}\text { Panel ADF- } \\
\text { statistic } \\
\text { Group rho- }\end{array}$ & $-4.574^{* * *}$ & 0.000 & $-15.394^{* * *}$ & 0.000 \\
& $\begin{array}{l}\text { statistic } \\
\text { Group PP- }\end{array}$ & 7.549 & 1.000 & $-5.791^{* * *}$ & 0.000 \\
& $\begin{array}{l}\text { statistic } \\
\text { Group ADF- }\end{array}$ & $-26.757^{* * *}$ & 0.000 & & \\
statistic & $-6.050^{* * *}$ & 0.000 & & \\
KAO & ADF & $-13.226^{* * *}$ & 0.000 & & \\
\hline
\end{tabular}

${ }^{*}, * *$ and ${ }^{* * *}$ represent significance at the $10 \%, 5 \%$ and $1 \%$ level, respectively.

To estimate the panel data sample, the Hausman test [59] is performed to choose a 
more appropriate model between a random effects model and a fixed effects model. The results in Table 5 reject the null hypothesis and therefore, a fixed effects model is used in the following estimation.

Table 5 Hausman test results

\begin{tabular}{lllll}
\hline Test Summary & Chi-Sq. Statistic & Chi-Sq. d.f. & Prob. & Model \\
\hline Cross-section random & 30.40 & 4 & 0.00 & $\begin{array}{l}\text { Fixed } \\
\text { effects }\end{array}$ \\
\hline
\end{tabular}

Considering the spatial effects, this research uses code developed by Sage [60]. Before the regression, Moran's I test is performed to make sure that the independent variables, like EE, and the dependent variables, like growth of energy efficiency, are correlated based on the trade flow. From the calculation of Moran's I index, which is shown in Table 6, the results show that the independent and dependent variables have a significant positive correlation.

Table 6 Moran's I index

\begin{tabular}{lc}
\hline Moran's I & Prob. \\
\hline $0.070 * * *$ & 0.000 \\
\hline$*, * *$ and $* * *$ & represent significance at the $10 \%, 5 \%$ and $1 \%$ level, respectively.
\end{tabular}

The results of the LM test [61] in Table 7 show that the spatial lags model (SAR) is more appropriate than the spatial error model (SEM). The significance level of the LM test with no spatial lag is more significant than that of the LM test with no spatial error. At the same time, the robust LM test with no spatial lag is more significant than the robust LM test with no spatial error.

Table 7 LM test results

\begin{tabular}{llllll}
\hline & $\begin{array}{l}\text { LM test: no } \\
\text { spatial lag }\end{array}$ & $\begin{array}{l}\text { Robust LM } \\
\text { test: no spatial } \\
\text { lag }\end{array}$ & $\begin{array}{l}\text { LM test: no } \\
\text { spatial error }\end{array}$ & $\begin{array}{l}\text { Robust LM } \\
\text { test: no spatial } \\
\text { error }\end{array}$ & Model \\
\hline P-value & $1.00 \times 10^{-12}$ & $7.87 \times 10^{-6}$ & $86.10 \times 10^{-12}$ & $802.99 \times 10^{-6}$ & SAR \\
\hline
\end{tabular}




\section{Estimation results}

\section{1. $\sigma$-convergence}

To explore the performance of $\sigma$-convergence, this study calculates the standard deviation of the logarithm of energy efficiency across different countries in the scope of the whole world and the selected regional cooperation mechanisms (Figure 1). Figure 1 indicates that the world average trend during the period from 2000 to 2014 declined in cross-country variance at the initial stage and increased in divergence in energy efficiency after 2010. That is, EE was convergent initially, but divergent after 2010.

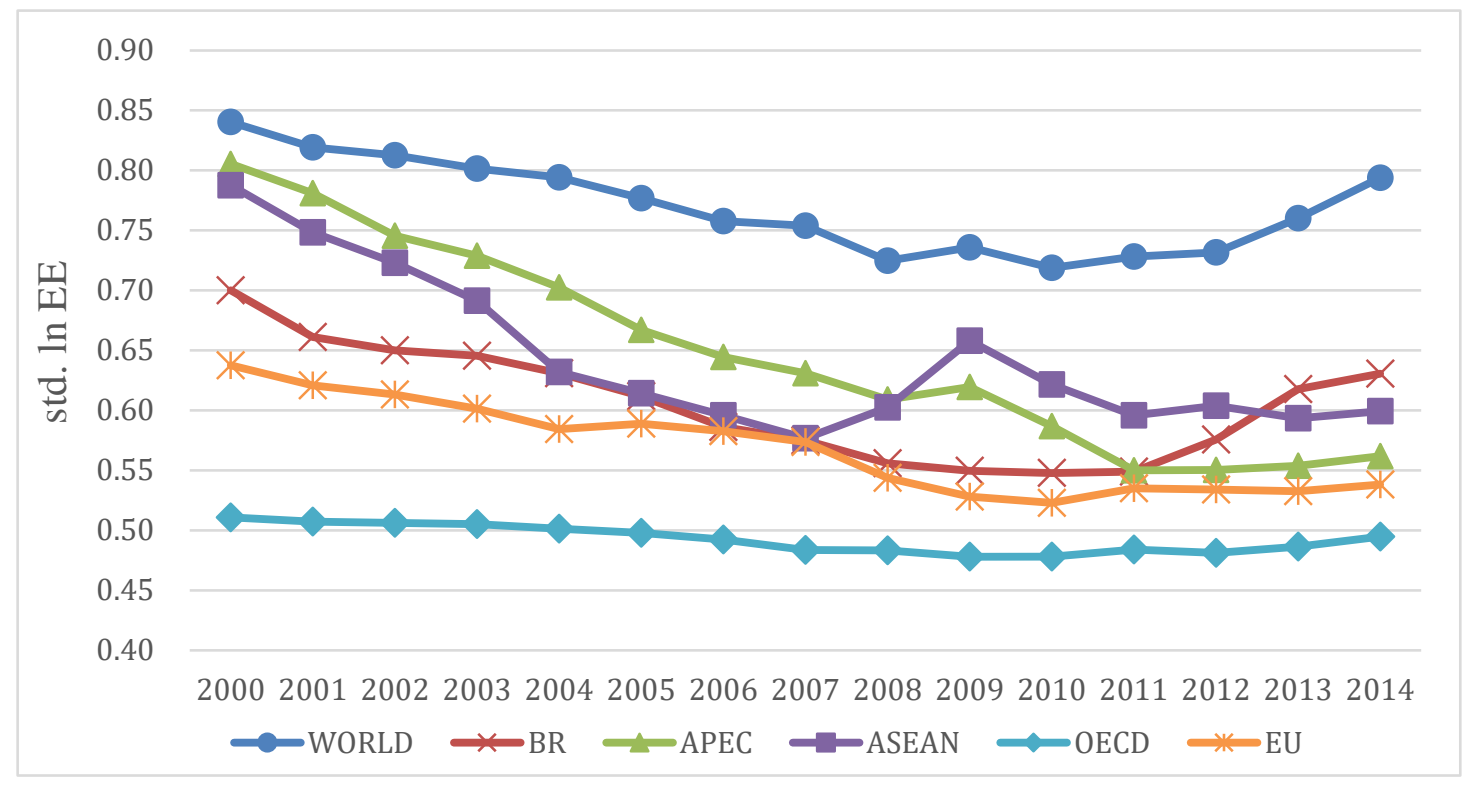

Fig. 1. Variance in energy efficiency across countries

However, among the countries in the APEC, ASEAN and EU, EE converges significantly. The OECD countries do not have a significant fluctuation. These results indicate that, within specific regional groups, the $\sigma$-convergence may be different from the general trend in the world and suggest that a regional cooperation mechanisms may promote EE convergence. At the same time, before the BR initiative has an impact in its scope, the BR countries show a larger gap in EE after 2010. Although the rate of divergence in BR countries is higher than the world average during the year of 2012 and 2013, the trend is similar to the world's general performance. The reasons why the BR countries have differences in convergence among these regional cooperation groups are as follows: First, all the groups have programmes for cooperation in energy and 
environment. For example, APEC and ASEAN have established dedicated cooperation mechanisms, including working groups, regular meetings and information exchange on energy efficiency issues [62, 63], which may have led to a narrower gap between member countries in EE. Second, all of these groups have been established for a long period, long enough for the policies to make a difference. In contrast, the effects of the BR initiative are not fully apparent yet. Third, many BR countries, especially the countries in Central Asia, have relatively lower openness compared with other groups. This may impede the process of cooperation in many fields, such as energy. Therefore, despite the fact that BR countries manifest a larger gap in EE after 2010, if the BR proves to strengthen regional cooperation in energy, the initiative can be beneficial for narrowing the EE gaps between BR countries in the future.

\section{2. $\beta$-convergence}

$\sigma$-convergence measures the gaps of EE across countries, while $\beta$-convergence analysis explores whether lagging countries can catch up with advanced ones in the long run given the control of some influential factors in the convergence process. This study next analyses $\beta$-convergence of EE and measures the effects of trade integration and regional cooperation.

In the regression, the general trend of EE convergence around the world is estimated first. The results of the SAR model are reported in Table 8. Considering spatial fixed effects, Column 1 presents the results of the unconditional convergence. The coefficient of $\ln \left(E E_{t-1}\right)$, which represents the convergence rate, is significantly negative. This implies that the world has a trend of convergence in EE generally. In other words, in terms of EE, lagging countries are catching up with advanced ones in the long run. A $1 \%$ increase in the energy efficiency in the last term leads to a $4.7 \%$ decrease in the growth rate of EE in the current period.

Next, this paper explores the convergence process controlling for conditional variables, such as trade integration (TI), energy mix (EM) and industrial structure (IS). The results in Table 8 (Column 4) indicate that, when considering the effects of conditional variables, the convergence evidence is consistent with the unconditional 
analysis. In other words, energy efficiency demonstrates absolute convergence overall—that is, the convergence will not be affected by external conditions.

Additionally, financial crises may affect energy consumption and intensity [64, 65]. Considering the impacts of the Global Financial Crisis around 2008 with lagging effects, the model divides the time interval into two parts with the year 2009 as a boundary: the first part is 2000 to 2008 (Table 8, Columns 2 and 5) and the second part is 2009 to 2014 (Table 8, Columns 3 and 6). The results show that in both the unconditional and conditional models, $\beta$-convergence is significant. The consistency of the results in the two different subsamples suggests that the influence of the financial crisis can be ignored in this analysis to some extent.

The state of convergence around the BR countries in the sample can also be found in Table 8. Before the BR initiative starts its effects, BR countries present a trend of convergence significantly, which is the same as the general EE performance around the world. The speed of convergence among the BR countries is higher than the average degree of the world. This means in the BR countries, there is a stronger tendency to converge.

\section{Table 8}

Results of the convergence analysis with spatial fixed effects

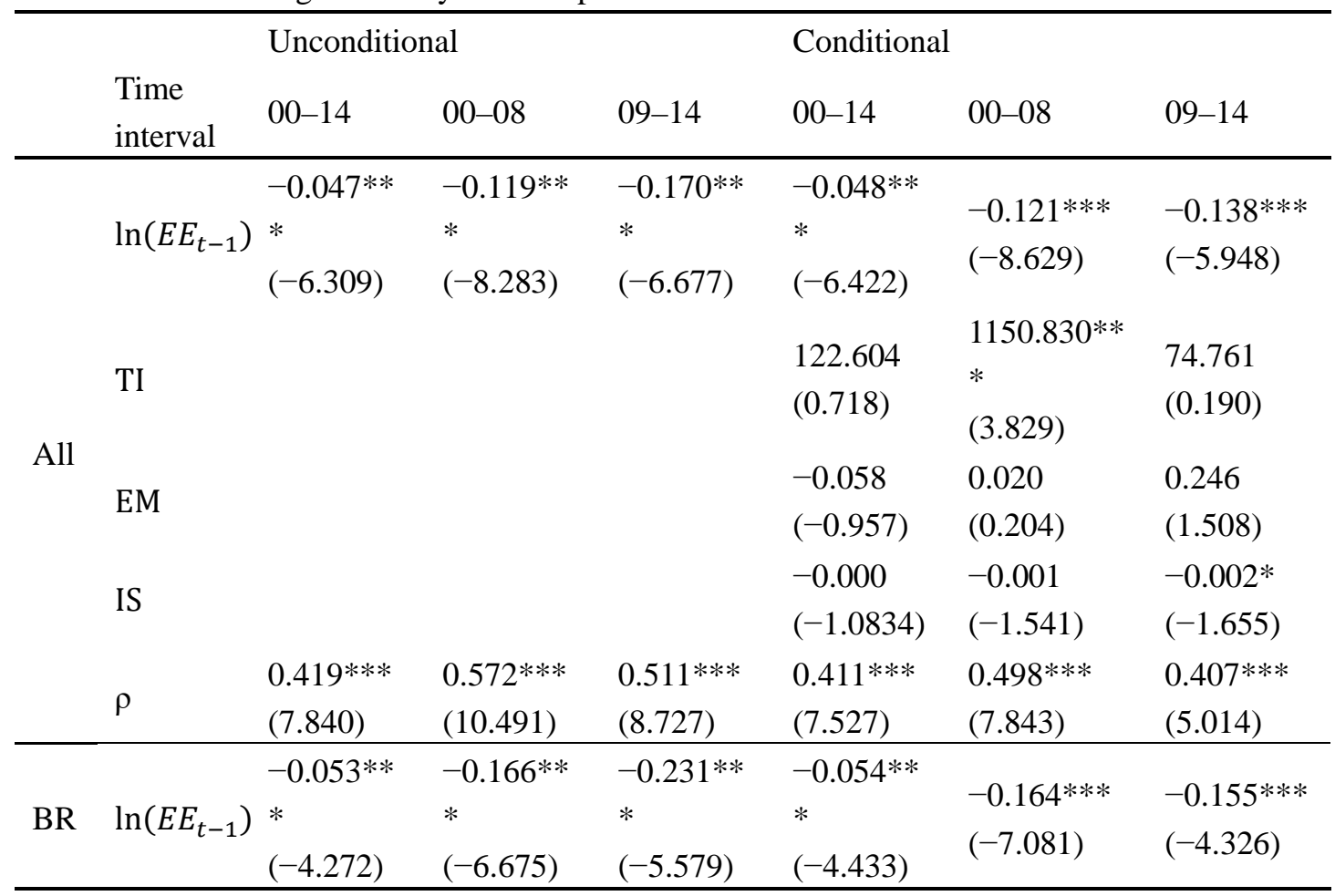




\begin{tabular}{|c|c|c|c|c|c|c|}
\hline TI & & & & $\begin{array}{l}337.036 \\
(1.625)\end{array}$ & $\begin{array}{l}1383.200 * * \\
* \\
(4.013)\end{array}$ & $\begin{array}{l}164.427 \\
(0.348)\end{array}$ \\
\hline EM & & & & $\begin{array}{l}-0.031 \\
(-0.295)\end{array}$ & $\begin{array}{l}0.002 \\
(0.012)\end{array}$ & $\begin{array}{l}0.187 \\
(0.748)\end{array}$ \\
\hline IS & & & & $\begin{array}{l}0.000 \\
(0.093)\end{array}$ & $\begin{array}{l}-0.001 \\
(-1.581)\end{array}$ & $\begin{array}{l}-0.002 \\
(-0.961)\end{array}$ \\
\hline$\rho$ & $\begin{array}{l}0.321 * * * \\
(4.750)\end{array}$ & $\begin{array}{l}0.336 * * * \\
(4.354)\end{array}$ & $\begin{array}{l}0.579 * * * \\
(8.761)\end{array}$ & $\begin{array}{l}0.314^{* * *} \\
(4.624)\end{array}$ & $\begin{array}{l}0.247 * * * \\
(3.071)\end{array}$ & $\begin{array}{l}0.481^{* * *} \\
(5.714)\end{array}$ \\
\hline
\end{tabular}

*, ** and ${ }^{* * *}$ represent significance at the $10 \%, 5 \%$ and $1 \%$ level, respectively.

According to the priorities of the BR initiative, one of the main objectives is to strengthen infrastructure (including energy) connectivity across Europe, Asia and Africa. To understand the characteristics in geography of the BR initiative better, the research next estimates the model grouped by continental distribution with a primary focus on Europe, Asia and Africa. In the sample, there are 36 European countries, 20 Asian countries and 15 African countries. The results are shown in Table 9. The results indicate that Europe, Asia and Africa all demonstrate significant convergence. The $\beta$ coefficient of Europe is the smallest, while that of Asia is the largest. According to the IMF classifications, 27 of 39 developed countries in the world are located in Europe. Since the European growth of EE has almost reached the steady state and thus, the degree of $\beta$-convergence seems lowest in Europe. Asia contains several significant emerging global economies, such as China, India and Korea. The divergence in the status of energy efficiency performance creates a higher potential to converge in EE in Asia during its rapid economic development.

Table 9

Results of the convergence analysis with spatial fixed effects grouped by continents

\begin{tabular}{llll}
\hline & Europe & Asia & Africa \\
\hline $\ln \left(E E_{t-1}\right)$ & $-0.053^{* * *}$ & $-0.092^{* * *}$ & $-0.063^{* * *}$ \\
& $(-5.042)$ & $(-4.162)$ & $(-3.668)$ \\
$\rho$ & $0.500^{* * *}$ & $0.369^{* * *}$ & 0.101 \\
& $(8.095)$ & $(4.475)$ & $(1.223)$ \\
\hline
\end{tabular}

$*$, ** and ${ }^{* * *}$ represent significance at the $10 \%, 5 \%$ and $1 \%$ level, respectively.

All in all, in the analysis of $\beta$-convergence, the performance of EE in lagging countries has the potential to catch up with advanced ones in the long run, despite the gaps in EE get larger after 2010. 


\subsection{Trade integration and EE convergence}

To explore whether trade integration can affect EE convergence, an interaction term is added to the model. As noted before, trade could lead to a shift of energy-intensive industries to countries with abundant energy resources and fewer stringent environmental regulations and thus, lead to divergence. On the contrary, trade can facilitate EE convergence due to several factors, such as the facts that trading of production factors changes the industrial structure; the trading of energy-related technology increases energy efficiency, improving the technology level; and trading leads to convergence of prices, making the energy mix converge. The results in Table 11 (Column 1) suggest that trade integration can push EE to converge when adding spatial fixed effects and controlling for conditional variables. At the same time, the coefficient of TI in Column 1 indicates trade integration can accelerate the formation of $\beta$-convergence, which means the growth rate is fast at first, decelerates as EE increases, and then approaches the steady state.

To further explore the differences among countries at different development levels, the 89 countries are classified into three groups according to their average GDP per capita from 2000 to 2014 (see Table 10). The distribution of continents indicates that the high-income countries are located mainly in Europe. Countries in Europe and the Americas account for a larger proportion of the middle-income group. The low-income countries are mainly in Africa and Asia. Although the three groups have their own characteristics, the distribution is relatively balanced; thus, the different groups represent different development stages to some degree.

\section{Table 10}

Description of the three income groups

\begin{tabular}{lcll}
\hline & Number & Representative & Continental distribution \\
\hline $\begin{array}{l}\text { High income } \\
\text { Middle }\end{array}$ & 30 & $\begin{array}{l}\text { Luxembourg, Norway, Switzerland, } \\
\text { etc. }\end{array}$ & $\begin{array}{l}\text { Europe (20); Asia (7); } \\
\text { Americas (2); Oceania (2); }\end{array}$ \\
$\begin{array}{l}\text { income } \\
\text { Low income }\end{array}$ & 29 & $\begin{array}{l}\text { Malta, Saudi Arabia, the Czech } \\
\text { Republic, etc. }\end{array}$ & $\begin{array}{l}\text { Europe (13); Americas } \\
\text { (10); Asia (5); Africa (2) } \\
\text { Thailand, Namibia, Ecuador, etc. }\end{array}$ \\
\hline
\end{tabular}


In Table 11 (Columns 2, 3 and 4), the results show the effects of trade integration on EE convergence at different development stages. The research finds that EE in all three groups converged from 2000 to 2014, and the coefficient of the high-income group is the largest. Controlling for conditional variables, in the middle- and lowincome groups, trade integration drives EE convergence, and the coefficients are much larger than the result in Column 1. This means that the impact of trade integration on EE convergence among the middle- and low-income groups is stronger than the world average. However, an effect of trade integration on the high-income group is not found.

Technology weaknesses in middle- and low-income countries could explain why there is a significant effect on EE convergence in the trade integration with China. Technical weakness can be demonstrated by the total patent grants per capita. The average value from 2000 to 2014 of the three groups was $5.280 \times 10^{-4}$ for the highincome group, $3.083 \times 10^{-5}$ for the middle-income group and $5.495 \times 10^{-6}$ for the lowincome group, respectively. For China, the value was $4.640 \times 10^{-5}$ [66], which is lower than the high-income countries but higher than the other two groups. The high-income countries' advanced and similar EE levels leave little room for further convergence. In contrast, the middle- and low-income groups can acquire benefits, like technology transfer, through trading with China and thus achieve convergence in EE. For the BR initiative, strengthening the trade integration with middle- and low-income countries can improve the EE convergence process among the countries.

\section{Table 11}

Results of the conditional convergence analysis with spatial fixed effects, with the interaction term of trade integration, grouped by development levels

\begin{tabular}{lllll}
\hline & All & High income & Middle income & Low income \\
\hline $\ln \left(E E_{t-1}\right)$ & $-0.047^{* * *}$ & $-0.152^{* * *}$ & $-0.039 * * *$ & $-0.042^{* * *}$ \\
& $(-6.247)$ & $(-5.823)$ & $(-3.376)$ & $(-2.6345)$ \\
$\mathrm{TI} * \ln \left(E E_{t-1}\right)$ & $-865.931^{* *}$ & -312.692 & $-1872.110^{* * *}$ & $-2278.796^{*}$ \\
& $(-2.381)$ & $(-0.492)$ & $(-2.590)$ & $(-1.6634)$ \\
$\mathrm{TI}$ & $13426.402^{* *}$ & 4845.466 & $28561.538^{* * *}$ & $33700.945^{*}$ \\
& $(2.402)$ & $(0.491)$ & $(2.585)$ & $(1.689)$ \\
$\mathrm{EM}$ & -0.076 & $-0.359 * * *$ & 0.146 & -0.148 \\
& $(-1.259)$ & $(-4.354)$ & $(1.247)$ & $(-1.165)$ \\
$\mathrm{IS}$ & -0.000 & $-0.000^{*}$ & -0.001 & $-0.003^{*}$ \\
& $(-1.213)$ & $(-1.841)$ & $(-0.741)$ & $(-1.834)$
\end{tabular}




\begin{tabular}{lllll}
$\rho$ & $0.409 * * *$ & $0.579 * * *$ & 0.085 & $0.222 * * *$ \\
& $(7.495)$ & $(10.292)$ & $(1.025)$ & $(3.241)$ \\
\hline
\end{tabular}

*, ** and ${ }^{* * *}$ represent significance at the $10 \%, 5 \%$ and $1 \%$ level, respectively.

\subsection{Regional cooperation and EE convergence}

To explore the role of regional cooperation in EE convergence, the APEC, ASEAN, OECD and EU are set as four dummy variables. According to the degree of relationship with China, these four RCMs are divided into two groups. One includes the APEC and ASEAN, both of which have a closer relationship with China. For example, the APEC includes China as a member, and the ASEAN has a close relationship with China through the ASEAN-China Free Trade Agreement (ACFTA), annual China-ASEAN summit and numerous ASEAN-China official dialogues and cooperation, including energy ministerial meetings and cooperation on EE, oil reserves and so on. The other group consists of the OECD and EU, in which the cooperation between these two RCMs and China seems relatively weak.

The coefficients of the interaction terms with the dummy variables show the effects of regional cooperation in specific RCMs, which can be found in Table 12. The results indicate that, except for the OECD, the APEC, ASEAN and EU all manifest positive influence on EE convergence. The coefficient $\beta$ of group 1 shows that the regional cooperation of the APEC and ASEAN has a stronger impact on the process of EE convergence than the OECD and EU. The reason why the OCED demonstrates an insignificant effect could be that the OECD countries are highly developed and have similar EE levels, thus, leaving no room to change the gap among the countries. Overall, the results suggest that regional cooperation may lead to EE convergence, which will also be applicable to the BR initiative.

Table 12

Results of conditional convergence analysis

\begin{tabular}{|c|c|c|c|c|}
\hline & \multicolumn{2}{|c|}{ Group 1} & \multicolumn{2}{|c|}{ Group 2} \\
\hline & Model 1 & Model 2 & Model 3 & Model 4 \\
\hline $\mathrm{APEC} * \ln \left(E E_{t-1}\right)$ & $\begin{array}{l}-0.075^{* * *} \\
(-3.166)\end{array}$ & & & \\
\hline $\operatorname{ASEAN} * \ln \left(E E_{t-1}\right)$ & & $\begin{array}{l}-0.135 * * * \\
(-3.661)\end{array}$ & & \\
\hline $\mathrm{OECD} * \ln \left(E E_{t-1}\right)$ & & & $\begin{array}{l}-0.000 \\
(-0.208)\end{array}$ & \\
\hline $\mathrm{EU} * \ln \left(E E_{t-1}\right)$ & & & & $-0.070 * * *$ \\
\hline
\end{tabular}




\begin{tabular}{lllll}
\hline & & & & $(-3.063)$ \\
TI $* \ln \left(E E_{t-1}\right)$ & $-1009.973^{* * *}$ & $-1099.708^{* * *}$ & $-1019.414^{* * *}$ & $-997.155^{* * *}$ \\
& $(-2.752)$ & $(-2.996)$ & $(-2.767)$ & $(-2.716)$ \\
TI & $15501.596^{* * *}$ & $16802.839 * * *$ & $15663.958^{* * *}$ & $15376.324^{* * *}$ \\
& $(2.747)$ & $(2.978)$ & $(2.765)$ & $(2.724)$ \\
EM & -0.086 & -0.095 & $-0.102^{*}$ & $-0.146^{* *}$ \\
& $(-1.406)$ & $(-1.552)$ & $(-1.654)$ & $(-2.320)$ \\
IS & -0.000 & -0.000 & -0.000 & -0.000 \\
& $(-0.848)$ & $(-0.941)$ & $(-0.806)$ & $(-1.043)$ \\
$\rho$ & $0.427 * * *$ & $0.440 * * *$ & $0.428 * * *$ & $0.427 * * *$ \\
& $(7.983)$ & $(8.265)$ & $(7.920)$ & $(7.920)$ \\
\hline
\end{tabular}

*, ** and ${ }^{* * *}$ represent significance at the $10 \%, 5 \%$ and $1 \%$ level, respectively.

\subsection{Growth of energy efficiency}

While EE convergence is an indicator that shows the most desirable outcome of various conditions, EE growth is also an important indicator. It is a necessary but not sufficient condition for EE convergence. EE growth demonstrates an improvement in the environment compared with the past. While such growth may not be faster than that in more developed countries, it is, however, a positive development.

In addition to the convergence analysis, the estimation results show that some conditions can promote EE growth. Table 8 shows that $41.1 \%$ to $57.2 \%$ of the unobserved portion of growth is explained by the spatial externality of bilateral trade, represented by the coefficient $\rho$ [12]. Table 11 shows that trade integration exerts a positive influence on the growth of EE except its positive contribution to EE convergence. This can also be found among middle-, and low-income economies (Table 10). In Table 11, the results indicate that an energy mix imposes a negative impact on the growth of EE in the high-income group, and a higher percentage of industry means a lower rate of EE growth in both high and low groups. Generally, high income countries have stable industrial systems and structures and thus the effects from the adjustment of industrial structure may be significant, but relatively weak. A practical channel for them to improve the EE performance is to use fuel with higher efficiency in production, like natural gas. For low-income countries, most are still in the process of industrialisation and energy-intensive industries are main drivers behind their economic development. In such a situation, reducing the proportion of energy-intensive industries through structural change can be an effective channel for them. 


\section{Discussion and implications for the BR initiative}

The empirical results suggest that, in the general trend around the world, the crosscountry variance increases after 2010, while there are still opportunities for lagging countries to catch up with their advanced counterparts in the long run. Trade integration and regional cooperation can promote the process of convergence. According to the comparison, the BR can potentially promote EE convergence through two channels: trade integration and regional cooperation.

On one hand, based on the results of the estimation, trade integration may lead to EE convergence, especially for middle- and low-income countries. The empirical evidence indicates that the effects of trade integration on EE convergence are positive in general across the world, with a much stronger influence among middle- and lowincome economies. This suggests that trade integration in the scope of the BR may have a positive impact on EE convergence, particularly in the middle- and low-income countries. The large proportion of middle- and low-income countries that are participating in the BR initiative will strengthen the impacts of BR. Among the current 37 BR countries in the sample, 30 (81\%) of the economies belong to these two income levels.

In addition, the impact of trade integration can be explained by the components of international trade. For example, mechanical and electrical products constitute a higher percentage of China's exports than other kinds of products. In 2014, the share was nearly 50\% [67]. The large share of mechanical and electrical products seen in the exports from China is found in lagging countries, like Vietnam $(30 \%, 2014)$ and India (38\%, 2014). The knowledge embodied in high-tech products, like mechanical and electrical products, from more advanced countries, can be transferred to improve the level of infrastructure and technology in lagging countries through bilateral trade. The boost in the technology level can accelerate the increase in EE [68-72]. With less space for the advanced countries to improve both in technology, and subsequently in EE, the lagging counterparts have more opportunities to catch up. Overall, in the scope of the BR initiative, trade integration may narrow the gaps in EE to some extent.

On the other hand, regional cooperation can promote EE convergence through 
enhanced relationships. For example, regional cooperation can facilitate the transfer of expertise, which is needed critically in lagging countries. Based on the comparative research, RCMs, such as the APEC, ASEAN and EU, are likely to lead to EE convergence. Notably, the APEC and ASEAN, which have a close relationship with China, have stronger impacts on the convergence process. The performance of the APEC and ASEAN further suggests that regional cooperation under the BR framework may also promote EE convergence.

Unlike the impact of trade integration with China on EE convergence that can be applied to the BR initiative in a straight forward way, the role of regional cooperation is more subtle. This research tries to support that notion by indicating the similar features between these high-profile RCMs and the BR initiative (Table 13). First, these RCMs have interests similar to those of the BR and, thus, their role in EE convergence may be applicable to the BR. Furthermore, the APEC has a similar structure to the BR in both the continental distribution and the development level of its members. From the data shown in Table 13, the BR initiative currently has 66 member economies (including China). Most of them are in Asia (65\%). The percentages of countries from other continents are 33\% for Europe and 2\% for Africa. In the APEC, 57\% of the members are Asian economies, 24\% are from the Americas, and 19\% are from Oceania. A similar structure can also be found not only in the APEC but also in the ASEAN. Overall, in the aspects of interested topics, continental distribution and development level, the estimated effects of the specific RCMs selected are reasonable. In other words, using the performance of these RCMs, especially the APEC, to deduce the implications for the BR initiative is reasonable. The results also offer a practical reference for policy makers to avoid potential negative impacts of the BR initiative.

Table 13

Comparison of international organisations

\begin{tabular}{|c|c|c|c|c|c|}
\hline & \multirow[b]{2}{*}{ Continents } & \multirow[b]{2}{*}{ Development level } & \multicolumn{2}{|c|}{ Topics } & \multirow[b]{2}{*}{ Scale } \\
\hline & & & $\begin{array}{l}\text { Energy } \\
\text { related }\end{array}$ & Trade & \\
\hline $\mathrm{BR}$ & $\begin{array}{l}\text { Europe }(22,33 \%) \\
\text { Asia }(43,65 \%) \\
\text { Africa }(1,2 \%)\end{array}$ & $\begin{array}{l}\text { Developed (10, 15\%) } \\
\text { Developing }(56,85 \%)\end{array}$ & $\sqrt{ }$ & $\sqrt{ }$ & 66 \\
\hline APEC & $\begin{array}{l}\text { Americas }(5,24 \%) \\
\text { Asia }(12,57 \%) \\
\text { Oceania }(4,19 \%)\end{array}$ & $\begin{array}{l}\text { Developed }(8,38 \%) \\
\text { Developing }(13,62 \%)\end{array}$ & $\sqrt{ }$ & $\sqrt{ }$ & 21 \\
\hline
\end{tabular}




\begin{tabular}{llllll}
\hline ASEAN & $\begin{array}{l}\text { Asia (11, 100\%) } \\
\text { Americas (4, 11\%) }\end{array}$ & $\begin{array}{l}\text { Developed (1, 9\%) } \\
\text { Developing (10,91\%) }\end{array}$ & $\sqrt{ }$ & $\sqrt{ }$ & 11 \\
OECD & $\begin{array}{l}\text { Europe (26, 74\%) } \\
\text { Asia (3, 9\%) } \\
\text { Oceania (2, 6\%) }\end{array}$ & $\begin{array}{l}\text { Developed (30, 86\%) } \\
\text { Developing (5, 14\%) }\end{array}$ & $\sqrt{ }$ & $\sqrt{ }$ & 35 \\
\multirow{2}{*}{ EU } & Europe (28, 100\%) & $\begin{array}{l}\text { Developed (23, 82\%) } \\
\text { Developing (5, 18\%) }\end{array}$ & $\sqrt{ }$ & $\sqrt{ }$ & \multirow{2}{*}{28} \\
\hline
\end{tabular}

The amount and percentage are shown in parentheses.

Moreover, in the view of the complementary advantages, the trade integration and regional cooperation channel can also help EE convergence among the BR countries. Emerging economies, like China and Russia, have more advanced technologies than the countries in Central Asia. In 2014, China granted a total number of 233,228 patents [66], including 16,465 energy-related patents. ${ }^{3}$ Russia granted 33,950 patents, and 1,276 were related to energy. By contrast, regarding the total number of patents granted, Kazakhstan had 1,504 and Turkmenistan had only one. The level of energy-related technology in other Central Asian countries is even lower.

Although Central Asian countries are technologically lagging, they usually have abundant energy resources, such as oil and natural gas. Kazakhstan's total proved reserves of oil in 2015 amounted to 3,900 million tonnes [73], while China had only 2,500 million tonnes. For natural gas, the total proved reserves of Turkmenistan were 617.3 trillion cubic feet, which is nearly five times the amount of China. However, compared with the resource endowments, the performance of energy production is quite poor. In 2015, Kazakhstan produced 79.3 million tonnes of oil, which was only $37 \%$ of China's production. The production of natural gas in Turkmenistan in the same year was 72.4 billion cubic metres, or about half of that of China.

Both China and the Central Asian countries will make EE improvements through cooperation. On the one hand, trade in natural gas will reduce the cost of energy use for China and improve the share of natural gas in the energy mix and the efficiency of fossil fuels. On the other hand, trade and investment in energy-related equipment or infrastructure can increase the technological progress of the Central Asian countries, achieving an upgrade in their industry.

\footnotetext{
${ }^{3}$ The definition of 'energy-related patents' is from the WIPO, and refers to electrical machinery, apparatus and energy.
} 
Compared to world average, China, Russia, Kazakhstan and Turkmenistan all have a far lower level of EE. From the statistics of the IEA and the World Bank, in 2014, the world EE was 8,342,994 (defined as GDP/TFC). The figures for China, Russia, Kazakhstan and Turkmenistan, mentioned above, were 5,273,262, 4,516,656, $6,049,860$ and 2,440,813, respectively. Therefore, to catch up with the better performance in EE, the relatively lagging countries along the BR routes can achieve a win-win situation by effectively using complementary advantages through trade integration and regional cooperation.

Relocation of industries across boundaries could also cause win-win outcomes for both the sourcing countries and the recipients. The East Asian miracle was due to the relocation of Japan's outdated (and often labour intensive) industries to Korea, Taiwan, Hong Kong and Singapore, and later, to China [74]. While an industry may be considered outdated in one country, it may be seen as advanced in another due to differences in comparative advantages, which are not only determined by resource endowment, but also by the level of economic development, such as labour and capital costs. Therefore, industrial relocation under the BR initiative is not necessarily negative, although the environmental impact and performance in recipient countries needs to be managed properly.

\section{Conclusion}

After China launched the BR initiative, the international community was concerned that the BR may worsen the environmental performance of the participating BR countries. This paper tries to explore the implications of the influence that China's BR initiative could have on the convergence of EE. The research first explores the $\sigma$ convergence among countries and finds that EE converged at the initial stage and diverged after 2010. However, in some specific regional cooperation mechanisms, energy efficiency converges significantly. Next, to analyse the effects of the BR initiative on EE convergence through trade integration and regional cooperation, a $\beta$ convergence model was built based on a trade-based spatial weight matrix.

The results show that the world's energy efficiency manifests a process of $\beta$ - 
convergence and that trade integration can push the general convergence of EE around the world. Besides, countries in Europe, Asia and Africa demonstrate significant EE convergence and Asia has the highest potential among them. After splitting the sample into three income groups, trade integration shows a stronger influence on the middleand low-income groups compared with the average level in the world. The effect on the high-income group is not significant. Enhancing the trade relationship between middleand low-income countries and China may achieve a better performance in EE convergence.

Next, four regional cooperation groups (the APEC, ASEAN, OECD and EU) were selected as representatives of typical mechanisms to study the potential effects of the BR initiative on EE convergence. The APEC and ASEAN, standing for the RCMS with closer cooperative relationships with China, have stronger impacts on EE convergence than the EU, while the impact of the OECD is ambiguous. These results suggest that regional cooperation mechanisms that have a close relationship with China have a more significant as well as stronger impact on EE convergence.

With reference to the BR initiative, the study suggests that this initiative could lead to EE convergence through two channels: trade integration (which creates a demand for energy resources) and regional cooperation (which facilitates information sharing and technology transfer). The impact of trade integration is more significant among the middle- and low-income countries; this highlights the significant potential of the BR initiative because a large proportion of the BR countries are in the middle- and lowincome groups. The impact of these channels can be explained further by the components of international trade, the complementary advantages and the transfer of expertise, which are made possible by either trade integration or regional cooperation or both. The contribution of industry relocation to the development of East Asia indicates that such relocation could achieve win-win outcomes. Overall, it suggests that the negative environmental concern of the BI initiative is not supported by evidence of deterioration in energy efficiency.

This paper has a weakness in that it cannot estimate empirically the impact of the BR initiative on EE convergence directly due to the nascent status of the BR. However, 
there is no better way to predict the impact of the BR. Yet it is of urgent importance that the concerns regarding the BR be addressed. In future, when the BR is in effect, conducting an empirical test of its impact on EE convergence would be a highly valuable contribution to all concerned.

\section{Acknowledgements}

This research is supported by the National Natural Science Foundation of China (No. 71673023), and China Scholarship Council ([2016]3100). Thanks for the proof and editing of Dr. Elspeth Thomson.

\section{References:}

[1] IEA. Market Report Series: Energy Efficiency 2017. Paris: International Energy Agency; 2017.

[2] IEA. World Energy Statistics and Balances. Paris: International Energy Agency; 2017.

[3] Barro RJ, Sala-i-Martin X. Convergence. Journal of political Economy. 1992;100:223-251.

[4] Mishra V, Smyth R. Convergence in energy consumption per capita among ASEAN countries. Energy Policy. 2014;73:180-185.

[5] Liddle B. Revisiting world energy intensity convergence for regional differences. Applied Energy. 2010;87:3218-3225.

[6] NDRC, NOFA, MOC. Vision and Actions on Jointly Building Silk Road Economic Belt and 21stCentury Maritime Silk Road. Beijing: National Development and Reform Commission, Ministry of Foreign Affairs, and Ministry of Commerce of the People's Republic of China; 2015.

[7] Michael L. China Argues Over 'Belt and Road’ Goals. Radio Free Asia. Washington2017.

[8] Berger R. Overcapacity in China: An impediment to the party's reform agenda. Beijing: Report prepared for The European Union Chamber of Commerce in China; 2015.

[9] Pieter B. Where Will China's 'One Belt, One Road' Initiative Lead?. Philadelphia: The Wharton School, University of Pennsylvania; 2017.

[10] Mulder P, De Groot HLF. Sectoral Energy- and Labour-Productivity Convergence. Environmental and Resource Economics. 2007;36:85-112.

[11] Mulder P. International specialization, sector structure and the evolution of manufacturing energy intensity in OECD countries. Energ J. 2015;36:111-136.

[12] Wan J, Baylis K, Mulder P. Trade-facilitated technology spillovers in energy productivity convergence processes across EU countries. Energy Economics. 2015;48:253-264.

[13] Sheng Y, Wu Y, Shi X, Zhang D. Energy trade efficiency and its determinants: A Malmquist index approach. Energy Economics. 2015;50:306-314.

[14] Geldi HK. Trade effects of regional integration: A panel cointegration analysis. Economic 
Modelling. 2012;29:1566-1570.

[15] Bahmani-Oskooee M, Bolhassani M, Hegerty SW. The effects of currency fluctuations and trade integration on industry trade between Canada and Mexico. Research in Economics. 2010;64:212-223.

[16] Vithessonthi C, Kumarasinghe S. Financial development, international trade integration, and stock market integration: Evidence from Asia. Journal of Multinational Financial Management. 2016;35:7992.

[17] Sheng Y, Shi X. Energy market integration and equitable growth across countries. Applied Energy. 2013;104:319-325.

[18] ACE. ASEAN Plan of Action for Energy Cooperation (APAEC) 2016-2025. Jakarta: ASEAN Centre for Energy; 2015.

[19] APEC. Sydney APEC Leaders' Declaration on Climate Change, Energy Security and Clean Development. Sydney: Asia-Pacific Economic Cooperation; 2007.

[20] APERC. Compendium of Energy Efficiency Policies OF APEC Economies. Tokyo: Asia Pacific Energy Research Centre; 2012.

[21] Miketa A, Mulder P. Energy productivity across developed and developing countries in 10 manufacturing sectors: Patterns of growth and convergence. Energy Economics. 2005;27:429-453.

[22] Taylor P, D' Ortigue O, Francoeur M, Trudeau N. Final energy use in IEA countries: The role of energy efficiency. Energy Policy. 2010;38:6463-6474.

[23] Mulder P, de Groot HLF. Structural change and convergence of energy intensity across OECD countries, 1970 - 2005. Energy Economics. 2012;34:1910-1921.

[24] Duro JA, Padilla E. Inequality across countries in energy intensities: An analysis of the role of energy transformation and final energy consumption. Energy Economics. 2011;33:474-479.

[25] Krugman P. Geography and trade. Southern Economic Journal. 1991;1.

[26] Duro JA, Alcántara V, Padilla E. International inequality in energy intensity levels and the role of production composition and energy efficiency: An analysis of OECD countries. Ecol Econ. 2010;69:2468-2474.

[27] Markandya A, Pedroso-Galinato S, Streimikiene D. Energy intensity in transition economies: Is there convergence towards the EU average? Energy Economics. 2006;28:121-145.

[28] Barro RJ, Sala-i-Martin X, Blanchard OJ, Hall RE. Convergence Across States and Regions. Brookings Papers on Economic Activity. Washington: Brookings Institution Press; 1991. p. 107-182.

[29] Adhikari D, Chen Y. Energy productivity convergence in Asian countries: A spatial panel data approach. International Journal of Economics and Finance. 2014;6:94.

[30] Wu Y. Spatial Econometric Analysis of Energy Efficiency Convergence of Chinese Provinces. Power and Energy Engineering Conference. Wuhan2009.

[31] Shaozhou Q, Wei L. Regional Economic Growth and Differences of Energy Intensity in China. Economic Research Journal. 2007;7:74-81.

[32] Shaozhou Q, Kai L. The Convergence Analysis of Differences of Regional Sectors Economic Growth and Energy Intensity. Economic Research Journal. 2010;2:109-122.

[33] Zhao X, Wesley Burnett J, Lacombe DJ. Province-level convergence of China' s carbon dioxide emissions. Applied Energy. 2015;150:286-295.

[34] Hao Y, Liao H, Wei YM. Is China' s carbon reduction target allocation reasonable? An analysis 
based on carbon intensity convergence. Applied Energy. 2015;142:229-239.

[35] Zhu ZS, Liao H, Cao HS. The differences of carbon intensity reduction rate across 89 countries in recent three decades. Applied Energy. 2014;113:808-815.

[36] Hao Y, Peng H. On the convergence in China's provincial per capita energy consumption: New evidence from a spatial econometric analysis. Energy Economics. 2017;68:31-43.

[37] Rey S, Janikas M. Regional convergence, inequality, and space. Journal of Economic Geography. 2005;5:155-176.

[38] Rey S, Montouri B. US regional income convergence: a spatial econometric perspective. Regional studies. 1999;33:143-156.

[39] Ang BW, Zhang FQ. A survey of index decomposition analysis in energy and environmental studies. Energy. 2000;25:1149-1176.

[40] Ang BW. LMDI decomposition approach: A guide for implementation. Energy Policy. 2015;86:233-238.

[41] Sun JW. The decrease in the difference of energy intensities between OECD countries from 1971 to 1998. Energy Policy. 2002;30:631-635.

[42] Huang Y. Understanding China's Belt \& Road Initiative: Motivation, framework and assessment. China Economic Review. 2016;40:314-321.

[43] Cheng LK. Three questions on China's “Belt and Road Initiative” . China Economic Review. 2016;40:309-313.

[44] Ze S, Chenxi Y. China' s Diplomatic Efforts to Promote Energy and Resources Cooperation Along the “One Belt and One Road” . Beijing: China Institute of International Studies; 2015.

[45] Brugier C. China' s way: the new Silk Road. Paris: European Union Institute for Security Studies; 2014.

[46] Abudureyimu A, Han Q. Clean energy development of Silk Road economic belt in Xinjiang. Applied Mechanics and Materials. 2014;521:846-849.

[47] Duan F, Ji Q, Liu B, Fan Y. Energy investment risk assessment for nations along China’ s Belt \& Road Initiative. J Clean Prod. 2018;170:535-547.

[48] Du J, Zhang Y. Does One Belt One Road Strategy Promote Chinese Overseas Direct Investment? China Economic Review. 2017.

[49] Keller W. International Trade, Foreign Direct Investment, and Technology Spillovers. NBER Working Paper. 2009;15442.

[50] Li H, Kingsley E. Economic structure and regional disparity in China: Beyond the Kuznets transition. International Regional Science Review. 2011;34:157-190.

[51] Berndt ER. Aggregate energy, efficiency, and productivity measurement. Annual Review of Energy. 1978;3:225-273.

[52] Cleveland CJ, Kaufmann RK, Stern DI. Aggregation and the role of energy in the economy. Ecol Econ. 2000;32:301-317.

[53] Kaufmann RK. The mechanisms for autonomous energy efficiency increases: A cointegration analysis of the US energy/GDP ratio. The Energy Journal. 2004:63-86.

[54] Mi Z, Pan S, Yu H, Wei Y. Potential impacts of industrial structure on energy consumption and CO2 emission: a case study of Beijing. J Clean Prod. 2015;103:455-462. 
[55] Maddala GS, Wu S. A Comparative Study of Unit Root Tests with Panel Data and a New Simple Test. OXFORD B ECON STAT. 1999;61:631-652.

[56] Levin A, Lin C, James Chu C. Unit root tests in panel data: asymptotic and finite-sample properties. J Econometrics. 2002;108:1-24.

[57] Kao C. Spurious regression and residual-based tests for cointegration in panel data. J Econometrics. 1999;90:1-44.

[58] Pedroni P. Critical values for cointegration tests in heterogeneous panels with multiple regressors. OXFORD B ECON STAT. 1999;61:653-670.

[59] Hausman, JA. A specification test in econometrics. Econometrica. 1978;46:1251-1271.

[60] James Le Sage RKP. Introduction to Spatial Econometrics. Abingdon: Taylor \& Francis Ltd; 2009.

[61] Anselin L, Bera AK, Florax R, Yoon MJ. Simple diagnostic tests for spatial dependence. Regional Science and Urban Economics. 1996;26:77-104.

[62] Shi X. Energy Efficiencies in ASEAN Region. The Handbook for Clean Energy Systems: John Wiley \& Sons, Ltd; 2015. p. 3681-3699.

[63] Shi X. Setting effective mandatory energy efficiency standards and labelling regulations: A review of best practices in the Asia Pacific region. Applied Energy. 2014;133:135-143.

[64] Timma L, Zoss T, Blumberga D. Life after the financial crisis. Energy intensity and energy use decomposition on sectorial level in Latvia. Applied Energy. 2016;162:1586-1592.

[65] Yuan C, Liu S, Xie N. The impact on Chinese economic growth and energy consumption of the Global Financial Crisis: An input - output analysis. Energy. 2010;35:1805-1812.

[66] WIPO. WIPO statistics database. Switzerland: World Intellectual Property Organization; 2016.

[67] CEIC. CEIC Data. Singapore: CEIC Data (SG) Pte Ltd; 2016.

[68] Fisher-Vanden K, Jefferson GH. What is driving China's decline in energy intensity? Resource and Energy Economics. 2004;26:77-97.

[69] Garbaccio RFHM. Controlling Carbon Emission in China. Environment and Development Economics. 1999;4:493-518.

[70] Mulder P. The economics of technology diffusion and energy efficiency. Cheltenham: Edward Elgar; 2005.

[71] Sue Wing I. Explaining the declining energy intensity of the U.S. economy. Resource and Energy Economics. 2008;30:21-49.

[72] Wei Y, Liao H, Fan Y. An empirical analysis of energy efficiency in China's iron and steel sector. Energy. 2007;32:2262-2270.

[73] BP. BP Statistical Review of World Energy. London: BP; 2016.

[74] Lloyd PJ. The role of foreign investment in the success of Asian industrialization. Journal of Asian Economics. 1996;7:407-433. 